\title{
Pilot Test of a Spanish Version of a Previously Validated HPV Survey that Evaluates Dental Students' Knowledge, Perception and Clinical Practices in Latin America
}

\section{Lilliam Pinzon \\ University of Utah}

\section{Alan Velazquez}

Universidad Autonoma de Baja California

Holdunn Rutkoski

Caring Health Center, United States

Djin Tay

University of Utah

Laura Martel

University of Utah

Carmen Drury

Huntsman Cancer Institute

Shauna Ayres

Huntsman Cancer Institute

\section{Barbara Dixon}

University of Utah

James Winkler

University of Utah

Deanna Kepka ( $\nabla$ deanna.kepka@hci.utah.edu )

University of Utah

\section{Research Article}

Keywords: Oropharyngeal cancer, HPV vaccination, Latin America, dental students, HPV survey

Posted Date: April 29th, 2021

DOl: https://doi.org/10.21203/rs.3.rs-420050/v1

License: (9) This work is licensed under a Creative Commons Attribution 4.0 International License.

Read Full License 
Page $2 / 21$ 


\section{Abstract}

Background: The global incidence of oropharyngeal cancer is increasing. Dental professionals play a key role in the detection of oral and OPC lesions that could lead to cancer. However, scientific-based HPV-OPC visual inspection guidelines are not fully defined. With sufficient knowledge and adequate training on how to educate patients about HPV vaccination, dental providers have the potential to lead HPV-OPC prevention. HPV knowledge and awareness has been reported to be low among dental student, oral health student, and oral health professional populations. Few if any of these studies have assessed the construct validity of instruments used to assess HPV knowledge and awareness among dental and oral health students and professionals.

Methods: This study aimed to evaluate the applicability of a Latin American Spanish translation of a multi-scale survey evaluating knowledge, perceptions, and clinical practices regarding HPV and HPV-OPC originally developed for English-speaking populations. Internal consistencies were measured using Cronbach Alpha. Analyses were conducted in SAS Version 9.4.

Results: Data from a total of 122 students, a majority of the which were female (58\%), aged 18 to 29 years old (93\%), and Hispanic/Latino(a)/Spanish (87\%). The HPV, HPV-OPC, and HPV vaccine knowledge subscales demonstrated good internal consistency, the Cronbach's alpha was $0.83,0.77$, and 0.85 respectively. The Barriers subscale had a Cronbach's alpha of 0.92 , showing a high internal consistency. The Clinical Procedures subscale focused on factors surrounding dental students' hypothetical clinical practice procedures and had a Cronbach's alpha of 0.80. The Scope of Practice scale had a Cronbach's alpha of 0.73 .

Conclusions. Ultimately, this survey demonstrated reliability and applicability for the assessment of dental students' knowledge, perceptions, and clinical practices regarding HPV and HPV-OPC in Latin America.

\section{Background}

The global incidence of oropharyngeal cancer (OPC) is increasing, especially among those younger than 45 years [1]. An estimated 9,180 new cases of OPC were reported in Latin America and the Caribbean in 2018 with $80 \%$ of these cases occurring in men [2]. The countries with the most OPC cases were Brazil, Venezuela, Cuba, Colombia, Mexico, and Argentina [3]. Epidemiological and in vitro research reports suggest a strong association of human papillomavirus (HPV) with OPC [4], which is further supported by reports from Mexico and Colombia stating that HPV is the attributable factor in $36 \%$ of OPC cases [5].

Dental professionals play a key role in the detection of any oral and OPC lesions that could lead to cancer [6]; however, scientific-based HPV-OPC visual inspection guidelines are still underdeveloped. Previous studies suggest that oropharyngeal cancer screening via oral rinse may be a useful tool to detect HPV associated OPC [7, 8]. However, the U.S. Food and Drug Administration (FDA) has yet to approve any tests to detect HPV in the oral cavity [9], making widespread HPV vaccination the leading prevention strategy to 
reduce the HPV-OPC burden. In an effort to increase HPV vaccination coverage, the FDA has recently approved HPV vaccine Gardasil-9 for men and women aged 27 to 45 years old [10]. Acknowledging the increase of HPV-OPC incidence, the American Dental Association's (ADA) recently adopted policy stating that dentists need to be current with HPV-OPC knowledge and support HPV vaccine use and administration [11].

With sufficient knowledge and adequate training on how to educate patients about HPV vaccination, dental providers have the potential to lead HPV-OPC prevention [12]. In fact, administering the HPV vaccine in the dental setting could be a viable option according to a multi-state study of United States (US) oral health students, where it was found that a majority of dental and dental hygiene students are open to be trained to administer the HPV vaccine [13]. Thus, it is crucial to evaluate dental professional's knowledge of, perceptions about, and clinical practices surrounding HPV and HPV vaccination. It is also important to understand what elements of dental school curriculum and clinical practices could improve HPV-OPC education and screening.

Globally, HPV knowledge and awareness has been reported to be low among the dental student, oral health student, and oral health professional populations; however, the construct validity of these instruments is questionable as many were study-specific [14-21]. Likewise, studies that examine HPV knowledge and awareness in Latin American countries are limited, but point to suboptimal levels of knowledge and awareness of HPV in countries such as Brazil and Ecuador [22, 23].

Validated instruments have been developed in the United States for HPV and HPV vaccine communication, advocacy, attitudes, and clinical practices among dental providers $[24,25,18]$.

Researchers from the University of Minnesota utilized a validated 32-item survey instrument designed to measure head and neck surgeon's knowledge, attitudes, and practices regarding HPV communication and vaccine advocacy with dentists and dental hygienists, and found a lack of knowledge about HPV and HPV vaccination [18]. However, all of these scales were developed for English-speaking respondents, and to our knowledge, none have been tested for applicability to Latin America, a region with a high burden of emerging HPV-OPC and low HPV knowledge and awareness.

This study aimed to evaluate the applicability of a Latin American Spanish translation of a multi-scale survey evaluating Knowledge, Perceptions, and Clinical Practices (KPCP) regarding HPV and HPV-OPC originally developed for English-speaking US dental and dental hygiene student populations [25]. The primary aim of the study was to assess the reliability of the survey subscales using Cronbach alpha. The secondary aim of the study was to examine the translated survey for linguistic and cultural equivalency using qualitative open-ended questions and in-person discussions.

It is crucial that the next generation of Latin American dental professions have the tools needed to improve the health and well-being of their patients through increasing HPV vaccination coverage. This can be achieved through HPV-OPC patient education [26], HPV vaccination recommendation, and preventative OPC screening [27]. Having a validated Spanish instrument evaluating KPCP for HPV and 
HPV-OPC would help identify areas of where Latin American dental schools could improve curriculum and secondarily help improve HPV-OPC prevention among their populations.

\section{Methods}

This study was conducted by researchers from the University of Utah School of Dentistry in Salt Lake City, Utah in the US and the Autonomous University of Baja California's Faculty of Dentistry in Tijuana, Mexico. Huntsman Cancer Institute and University of Utah School of Medicine also supported this research.

\section{Questionnaire Development}

This pilot study adapted a previously developed questionnaire for English-speaking oral health students. The translation of the pilot test questionnaire was done by two native Spanish-speaking members of the research team (LMP \& AV) who are also fluent in the source language. Forward translation was done by a researcher who is a certified bilingual translator (LMP). The initial version was evaluated for sematic equivalence by the appointed in-country investigator (AV), who also served as an editor and highlighted grammatical and typographic errors. Reconciliation of forward translation concerns was made via a discussion between the members of the research team and a final version of the translated survey was made when all concerns were resolved. The resulting translated version was tested in this pilot study.

The HPV-OPC Knowledge, Perceptions, and Clinical Practices (KPCP) Spanish Version (SV) consisted of 147 items, of which 106 items were included in the final analysis. Items made up seven subscales: 1) HPV knowledge, 2) HPV-OPC knowledge, 3) HPV vaccine knowledge, 4) Barriers, 5) Clinical Procedures, 6) Scope of Practice, and 7) Curriculum Evaluation. The questionnaire also included demographic questions. The questions had a variety of response types, including true/false/don't-know, multiple choice, check all that apply, yes/no, and Likert scale. The pilot test survey questionnaire took between 30-40 minutes to complete. Approval from University of Utah's and Institutional Review Board (IRB), also known at the university's ethics committee, was obtained prior to this study (IRB_00087209).

\section{Questionnaire Pilot Testing}

Throughout Latin America, email invitations were sent to eight universities to participate in this pilot study, from which two agreed to participate; one program was located in Colombia (Facultad de Odontología de la Universidad de Antioquia) and the other, in Mexico (Facultad de Odontología de la Universidad Autónoma de Baja California, Tijuana campus). The two schools selected for this study are located in geographical regions where dental student's HPV-OPC knowledge has not been evaluated before. Thus, they were both good candidates to pilot test the HPV-OPC-KPCP-SV instrument and measure internal consistency. Eligible participants were first year dental (D1) students as they perform oral health educational duties as part of their program requirements. Since D1 student participants had not completed oral pathology curriculum prior to the pilot, the investigators were cautious in interpreting the knowledge section's accuracy and focuses on internal consistency. Study procedures were conducted 
by two of the study investigators (Colombia-LMP; Mexico-AV) according to the IRB-approved study protocol in both sites to ensure consistency. First, study investigators gave a short oral presentation about the research project to D1 students. Students were then instructed on how to properly answer the questions and then completed the questionnaire at their own pace. The questionnaire was administered in pencil-and-paper format, and then study investigators manually entered the data into Vanderbilt University's Research Electronic Data Capture (REDCap) program for data management.

Students took between 30 to 40 minutes to complete the questionnaire, after which, they participated in an in-person discussion for about 30 minutes. During the in-person discussion, issues related to the survey questions were reviewed to gain additional feedback. Participants also provided their overall impressions of the instrument, suggested changes, shared what they liked or disliked about the instrument, and provided feedback on the order of questions. D1 students were incentivized to participate in the study by holding three raffles per University with the opportunity to win clinical dental instruments. Raffles were done immediately after participants finished the questionnaire and discussion. Analyses were conducted using SAS software, Version 9.4.

\section{Results}

A total of $N=122$ Latin American dental students participated in this study. The majority of participants were female (58\%), aged 18 to 29 years old (93\%), Hispanic/Latino(a)/Spanish (87\%), and had at least an undergraduate associate or bachelor's degree prior to entering their dental program (95\%). Table 1 contains a complete breakdown of participant demographics. 
Table 1

Demographic characteristics of participants; $\mathrm{N}=122[\mathrm{~N}(\%)]$

\begin{tabular}{|ll|}
\hline Sex & $71(58 \%)$ \\
\hline Female & $45(36 \%)$ \\
\hline Male & $6(5 \%)$ \\
\hline Prefer not to answer & \\
\hline Age & $2(2 \%)$ \\
\hline$<18$ & $114(93 \%)$ \\
\hline $18-29$ & $6(5 \%)$ \\
\hline Did not answer & \\
\hline Religion & $4(3.2 \%)$ \\
\hline Agnostic & $3(2.4 \%)$ \\
\hline Atheist & $1(0.8 \%)$ \\
\hline Buddhist & $69(56.5 \%)$ \\
\hline Catholic & $2(1.6 \%)$ \\
\hline Jehovah's witness & $1(0.8 \%)$ \\
\hline Jewish & $3(2.4 \%)$ \\
\hline Mormon/LDS & $3(2.4 \%)$ \\
\hline Protestant & $9(7.3 \%)$ \\
\hline Other & $6(4.9 \%)$ \\
\hline Nothing in particular & $11(9 \%)$ \\
\hline Prefer not to answer & $10(8.1 \%)$ \\
\hline Did not answer & $25(20 \%)$ \\
\hline Prior degrees earned & \\
\hline Associate degree & $(75 \%)$ \\
\hline Bachelor's degree & \\
\hline Master's degree & $2.8 \%)$ \\
\hline Doctorate degree & \\
\hline
\end{tabular}


Table 2 contains a summary of the HPV-OPC-KPCP-SV scale reliability and correlation coefficients, the type of analysis performed, and the number of questions included in each scale. The HPV, HPV-OPC, and HPV vaccine knowledge subscales demonstrated good internal consistency, the Cronbach's alpha (a) was $0.83,0.77$, and 0.85 respectively. The Barriers subscale had a Cronbach's alpha of 0.92 , showing a high internal consistency. The Clinical Procedures subscale focused on factors surrounding dental students' hypothetical clinical practice procedures and had a Cronbach's alpha of 0.80 . The Scope of Practice scale had a Cronbach's alpha of 0.73. The Curriculum Evaluation scale had a Cronbach's alpha of 0.23; however this is likely due to the differences in curriculum between dental schools and differences in geographical regions (U.S. vs Mexico and Colombia). The questions used for these analyses are shown in Table 3. Qualitative comments from students were also concurrently reviewed. Overall, discussion feedback was positive, with some suggestions for improvement regarding missing accents and minor rewording of certain items.

Table 2

Summary of reliability and correlation coefficients of subscales

\begin{tabular}{|lll|}
\hline Subscales & Cronbach alpha & Items \\
\hline 1. HPV knowledge & 0.83 & 22 \\
\hline 2. HPV-OPC knowledge & 0.77 & 13 \\
\hline 3. HPV vaccine knowledge & 0.85 & 25 \\
\hline 4. Barriers & 0.92 & 24 \\
\hline 5. Clinical Procedures & 0.80 & 11 \\
\hline 6. Scope of practice & 0.73 & 11 \\
\hline 7. Curriculum Evaluation & 0.23 & 12 \\
\hline
\end{tabular}


Table 3

Subscale items analyzed for reliability

\section{HPV knowledge}

Hay muchos tipos de Virus de Papiloma Humano (VPH)

VPH es una infección bacteriana

Una persona puede estar infectado con VPH sin saberlo

Generalmente, casi todas las infecciones de VPH se resuelven espontáneamente después de dos años

El VPH puede ser transmitido por contacto sexual

Una persona sin verrugas genitales puede transmitir el VPH

VPH puede causar cáncer orofaríngeo

VPH puede causar herpes

VPH puede causar VIH/SIDA

VPH puede causar verrugas genitales

VPH puede causar cáncer de cérvix

La tasa de VPH es más alta en mujeres

La displasia relacionada con VPH es mas común en personas fumadoras

VPH puede causar resultados anormales del examen Papanicolaou

Las verrugas genitales son causadas por el mismo tipo de VPH que causa cáncer de orofaríngeo

Las verrugas genitales son causadas por el mismo tipo de VPH que causa cáncer de cérvix

Casi todos los canceres cervicales son causados por el VPH

Usar condón disminuye la posibilidad de contraer y de transmitir el VPH

Inclusive después de ser vacunado contra el VPH el uso de condón puede proveer protección de otras enfermedades sexualmente transmisibles $\mathrm{y} / \mathrm{o}$ infecciones de VPH

Los antibióticos puedes curar el VPH
There are many types of Human

Papillomavirus (HPV)

HPV is a bacterial infection

A person can have HPV without knowing it

Generally, most HPV infections resolve spontaneously within 2 years

HPV can be transmitted via sexual contact

A person can transmit HPV even if a genital wart is not present

HPV can cause oropharyngeal cancer

HPV can cause herpes

HPV can cause HIV/AIDS

HPV can cause genital warts

Some types of HPV cause cervical cancer

The rate of HPV is highest among women

HPV related dysplasia occurs more commonly in smokers

HPV can cause an abnormal Pap smear test/Pap test in women

Genital warts are caused by the same HPV type(s) that cause oropharyngeal cancer

Genital warts are caused by the same HPV type(s) that cause cervical cancer

Almost all cervical cancers are caused by HPV

Using a condom will decrease the chance of transmitting/acquiring HPV

Even after HPV vaccination, condoms continue to provide protection against future sexually transmitted infections (STIs) and/or HPV infections

Antibiotics can cure HPV 


\section{HPV knowledge}

El cáncer orofaríngeo como resultado del consumo de tabaco (cigarrillos) es una causa de muerte más común que el cáncer orofaríngeo causado por el VPH

Las etapas tempranas de cáncer orofaríngeo asociado con VPH son a menudo asintomáticas

\section{HPV-OPC knowledge}

En un consultorio odontológico, ¿qué tan seguido debe un paciente recibir un examen oral y de cabeza y cuello para evaluar lesiones que pueden ser cancerosas?

¿En qué grupo de edades se debe realizar examinación oral y de cabeza y cuello para evaluar lesiones que pueden ser cancerosas?

¿Qué grupo étnico/racial tiene la tasa más alta de cáncer orofaríngeo?

¿En cuál grupo de edades se tiene la tasa más alta de cáncer orofaríngeo?

¿Cuál sexo/genero tiene la tasa más alta de cáncer orofaríngeo?

¿Cuál grupo de edades se tiene la tasa más alta infección con VPH?

¿Qué porcentaje de cáncer orofaríngeo es atribuido al VPH?

Durante los últimos 10 años, ¿cuál de todas las áreas de la cavidad oral mencionadas abajo ha presentado la mayor tasa de cáncer orofaríngeo asociado al VPH?

Durante los últimos 10 años, ¿cuál grupo de edad ha mostrado el mayor incremento de tasa de cáncer orofaríngeo?

¿Cuál de estos profesionales son fuentes de conocimiento clínico confiable sobre cáncer orofaríngeo asociado al VPH?

Discutir la asociación entre cáncer orofaríngeo y el VPH es parte del rol del odontólogo

Recomendar a un paciente la vacuna del VPH es parte del rol profesional del odontólogo

La administración de la vacuna del VPH en el consultorio odontológico es parte del rol profesional del odontólogo
Oropharyngeal cancer caused by smoking is more deadly than oropharyngeal cancer caused by HPV

Early stages of HPV oropharyngeal cancer are often asymptomatic
In the dental office, how often should a patient receive an oral, head, and neck cancer examination?

Which age group(s) should an oral, head, and neck cancer examination be performed on?

Which ethnic/racial background has the highest rate of oropharyngeal cancer?

Which age group has the highest rate of oropharyngeal cancer?

Which sex/gender has the highest rate of oropharyngeal cancer?

While age group has the highest rate of HPV infections?

What percentage of oropharyngeal cancer is attributed to HPV?

Over the last ten years, which of the following oral locations had the most increase in rate for HPV related oropharyngeal cancer?

Over the last ten years, which age group has shown the most increase in rate for HPV related oropharyngeal cancer?

Which of the following professionals are the most reliable clinical sources of HPV and oropharyngeal cancer information?

Discussing the link between HPV and oropharyngeal cancer falls within the scope and role of a dental professional.

Recommending HPV vaccination falls within the scope and role of a dental professional.

Administering the HPV vaccines inside the dental office falls within the scope and role of a dental professional. 


\section{HPV knowledge}

\section{HPV vaccine knowledge}

¿Sabías algo sobre el VPH antes de responder este cuestionario?

Hay unas vacunas que proveen inmunidad en contra ciertos tipos de VPH

La efectividad de la vacuna del VPH no disminuye con el tiempo

Las vacunas del VPH protegen a las mujeres de contraer cáncer cervical asociado al VPH

Las vacunas del VPH protegen a las mujeres de contraer cáncer orofaríngeo asociado al VPH

Las vacunas del VPH protegen a las mujeres de contraer cáncer anal asociado al VPH

Las vacunas del VPH no protegen a un individuo de todos los tipos de VPH

Individuos vacunados en contra del VPH no tienen que preocuparse de tener sexo seguro

La vacunación en contra del VPH incrementa la posibilidad de que las personas incurran en actividades sexuales de riesgo

Generalmente, las vacunas del VPH son seguras

En general, las vacunas del VPH no causan efectos secundarios serios

Las vacunas de VPH son muy costosas para personas sin seguro médico

Las vacunas de VPH son cubiertas por casi todos los seguros médicos

Las vacunas de VPH son administradas en una sola dosis

Las vacunas de VPH pueden proteger a las mujeres y hombre de las verrugas genitales asociadas a VPH

Personas con verrugas genitales no pueden ser vacunados con la vacuna del VPH

La vacuna del VPH es efectiva solo en personas que no han tenido ningún tipo de contacto sexual

Estar en una relación monógama elimina el riesgo de infectarse con VPH
Were you aware of the HPV vaccines before taking this survey?

There are vaccines that provide immunity against certain types of HPV

The effectiveness of the HPV vaccine does not decrease over time

HPV vaccines can protect women against HPV related cervical cancer

HPV vaccines can protect women against HPV related oropharyngeal cancer

HPV vaccines can protect men and women against HPV related anal cancer

HPV vaccines do not protect an individual from all types of HPV

Individuals who receive the HPV vaccines do not have to be concerned with practicing safe sex (e.g. using condoms)

HPV vaccination increases the likelihood of people engaging in risky sexual behaviors (e.g. multiple partners, unprotected sex, etc.)

Generally, HPV vaccines are safe

In general, HPV vaccines do not cause serious side effects

HPV vaccines are expensive for uninsured individuals

HPV vaccines are covered by most insurance providers

HPV vaccines are administered in one dose

HPV vaccines can protect men and women against HPV related genital warts

People who already had genital warts cannot get the HPV vaccines

HPV vaccines are only effective for individuals who have never had sex

Being in a monogamous relationship eliminates your risk of HPV infection 


\section{HPV knowledge}

Mujeres con resultados anormales de Papanicolaou no deben ser vacunas la vacuna del VPH

El centro de control y prevención de enfermedades (CDC) recomienda la vacunación de VPH para mujeres y hombres

Discutir con sus pacientes sobre VPH le permite tener una conversación con sus pacientes sobre el comportamiento sexual de ellos

Las vacunas de VPH son altamente efectivas para la prevención de precursores de cáncer cervical

¿Cuándo es recomendada idealmente la vacuna del VPH?

¿Cuál es la edad optima para administrar la vacuna del VPH a las mujeres?

¿Cuál es la edad optima para administrar la vacuna del VPH a los hombres?
Women who have had an abnormal Pap smear/Pap test should not receive the HPV vaccines

The Centers for Disease Control and Prevention (CDC) recommends that the HPV vaccines should be administered to both males and female

Discussing the HPV vaccines provide an opportunity to have a conversation with your patients about their sexual behaviors (e.g. sexual history, practicing safe sex, etc.)

HPV vaccines are highly effective at preventing cervical cancer precursors

When is HPV vaccination ideally recommended?

What is the optimal age for HPV vaccination in females?

What is the optimal age for HPV vaccination in males?

\section{Barriers}

Basado en su experiencia como profesional de la salud oral, ¿qué tan difícil o fácil es discutir los siguientes temas con sus pacientes?

Abuso (ejemplo: violencia domestica, abuso a menores, abuso adulto mayor)

Desordenes alimenticios

Historia de enfermedades sexualmente transmisibles (ETS)

Comportamientos sexuales (ejemplo: sexo oral, sexo anal)

Consumo y dependencia de sustancias psicoactivas (tabaco, alcohol, drogas)

Historial de vacunas

El paciente es del sexo opuesto

No hay suficiente tiempo para discutir el tema durante la cita

No me siento cómodo(a) con el tema
Based on your experience, how difficult or easy is it to discuss the following topics with your patients?

Abuse (e.g., domestic violence, child abuse, elder abuse)

\section{Eating disorders}

Sexually transmitted infection (STI or STD) history

Sexual behaviors (e.g. oral sex, anal sex)

Substance use disorders (e.g. tobacco use, alcohol use, illicit drugs)

Vaccination history

The patient is of the opposite sex

There is not enough time to discuss this during appointments

I do not feel comfortable with the topic 


\section{HPV knowledge}

Miembros adicionales del equipo odontológico deberían estar en el consultorio

Problemas de confidencialidad

El paciente era un menor de edad

Hay mucha diferencia de edad (mayor/menor) entre el paciente y yo

No creo que sea mi papel como profesional de la salud oral discutir la historia sexual de los pacientes

El diseño físico de mi consultorio no proporciona suficiente privacidad

No tengo suficiente información acerca de las vacunas contra el VPH

Estoy preocupado por la seguridad de las vacunas contra el VPH

Razones de responsabilidad legal

No creo que sea mi papel como profesional de la salud oral recomendar vacunas contra el VPH a mis pacientes

No hay políticas establecidas ni guías profesionales pertinentes en la recomendación de la vacuna contra $\mathrm{VPH}$

No hay suficiente tiempo para discutir el tema en las citas

No me siento cómodo hablando de la historia sexual con mis pacientes o de temas relacionados

Las normas sociales y culturales juegan un papel en la discusión del VPH y de las vacunas contra el VPH en el consultorio odontológico

La ideología religiosa del paciente juega un papel en la discusión del VPH y de las vacunas contra el VPH en el consultorio odontológico
Additional dental team members would also have to be in the room

Confidentiality issues

The patient was a minor

There was a large age difference (older/younger) between the patient and me

I do not believe it is my role as an oral health professional to discuss a patient's sexual history

The physical layout of my office does not afford enough privacy (e.g., other patients' presence in a larger exam area, no doors on the exam room, etc.)

I do not have enough information about the HPV vaccine

I am concerned with the safety of the HPV vaccines

Liability reasons

I do not believe it is my role as an oral health professional to recommend the HPV vaccines to my patients

There are no established professional policies/guidelines pertaining to recommendation of the HPV vaccines

There is not enough time to discuss this during appointments

I am not comfortable discussing sexual history/topics with patients

Social and cultural norms play a role in discussing HPV and the HPV vaccines in the dental office

A patient's religious ideology plays a role in discussing HPV and the HPV vaccines in the dental office

\section{Clinical Procedures}

¿Cuál de las siguientes opciones describe mas apropiadamente su procedimiento normal para conversar con sus pacientes sobre el propósito y resultados de las evaluaciones de cáncer oral y de cabeza y cuello?
Which of the following describes your typical approach in communicating with patients about the purpose and the results of their oral, head, and neck cancer examination? 


\section{HPV knowledge}

Si usted tuviera que discutir la relación entre VPH y el cáncer orofaríngeo con sus pacientes, ¿cuál de los siguientes puntos cree usted que facilitarían esta conversación?

¿Cuál frase describe mejor como usted se comunica con pacientes acerca de las vacunas contra el VPH?
If you were to discuss the relationship between HPV and oropharyngeal cancer with your patients, which of the following do you think would best facilitate this conversation?

Which statement best describes how you communicate with patients about the HPV vaccines?

Which statement best describes how you communicate with patients about their oral/systemic health?

Which statement best describes how you communicate with patients about the HPV vaccines?
¿Cuál frase describe mejor como usted comunica a sus pacientes la conexión de la salud oral y sistémica?

¿Cuál frase describe mejor como usted se comunica con pacientes acerca de su historia sexual?

De los métodos listados a continuación, ¿cuál cree usted produciría la información más certera respecto a la historia sexual de los pacientes?
Which statement best describes how you communicate with patients about their sexual history?

\section{Scope of Practice}

¿Usted estaría interesado en participar en un entrenamiento para administrar vacunas contra el VPH en su práctica odontológica?

¿Usted estaría interesado en participar en un entrenamiento para administrar vacunas contra de la influenza/gripe en su práctica odontológica?

Si recibiera entrenamiento, ¿usted estaría interesado en administrar vacunas contra el VPH en su practica odontológica?

Si fuera adecuadamente entrenado, ¿qué tan dispuesto estaría de administrar la vacuna contra la gripe en su consultorio odontológico?
How willing would you be to participate in a training to administer the HPV vaccines in your dental practice?

How willing would you be to participate in a training to administer the flu vaccines in your dental practice?

If trained, how willing would you be to administer the HPV vaccines in your dental office?

If properly trained, how willing would you be to administer the flu vaccine in your dental office?

\section{Curriculum evaluation}

¿Cuál(es) estructura(s) examina usted visualmente durante una evaluación de cáncer oral y/o de cabezo y cuello?

¿Cuál estructura palpa usted durante una evaluación de cáncer oral y/o de cabeza y cuello?

¿Qué tan buena ha sido su educación en odontología para hacer una evaluación de cáncer oral y de cabeza y cuello?

¿Qué tanta confianza tiene en su habilidad para hacer una evaluación de cáncer oral y de cabeza y cuello?
Which structure(s) do you visually examine during an oral, head, and neck cancer examination?

Which structure(s) do you palpate during an oral, head, and neck cancer examination?

How well has your dental education prepared you to perform an oral, head, and neck cancer examination?

How confident are you in your ability to perform an oral, head, and neck cancer examination? 


\section{HPV knowledge}

¿Con qué frecuencia se ha discutido durante su educación odontológica sobre el VPH y la relación entre el VPH y el cáncer orofaríngeo?

¿Hasta que punto está de acuerdo con la siguiente declaración: "mi plan de estudios odontológicos debería haber tenido más énfasis sobre la asociación del VPH con el cáncer orofaríngeo?

¿Cuál de las siguientes metodologías fueron utilizadas por su facultad de odontología para educarlos en el tema del VPH?

Durante su educación formal como estudiante de odontología, ¿dónde aprendió acerca de la relación entre VPH y cáncer orofaríngeo?

¿Cuáles son los factores de riesgo más comunes del cáncer orofaríngeo asociado al VPH?

¿Cuál es el área mas común para realizar biopsia de diagnóstico del cáncer orofaríngeo asociado al VPH?

Existen estándares o pruebas de rutina para el cáncer orofaríngeo específicamente

¿Cuáles de los siguientes puntos están presente en la historia clínica de su facultad de odontología?
How frequently has HPV or HPV related oropharyngeal cancer been discussed during your dental education?

What is your level of agreement with the following statement: "More emphasis should have been placed on HPV related oropharyngeal cancer education during my dental curriculum."

Which of the following methodologies were used for HPV education by your dental institution?

During your formal dental education training, where did you learn about the link between HPV and oropharyngeal cancer?

What are the probable risk factors for HPV oropharyngeal cancer?

Where is the most common location for a HPV related oropharyngeal cancer biopsy?

There are standards or routine screening tests for oropharyngeal cancer, specifically.

Based on what you remember, which of the following items are included on the medical history forms at your dental school?

\section{Discussion}

This pilot study aimed to evaluate internal consistency of the HPV-OPC Knowledge, Perceptions, and Clinical Practices (KPCP) Spanish Version (SV) in a sample of Latin American dental students, which was adapted from a previously validated English version. The main findings indicate high internal consistency of most subscales in the instrument. Feedback received from students suggest some minor orthographical and grammatical corrections, as well as to specify when questions are single or multiple option response. In general, there was evidence of equivalence between the HPV-OPC-KPCP-SV and the English version. Culturally, the survey also demonstrated strong practical relevance for students in Latin American countries, as participants expressed interest in acquiring knowledge related to the topic through open-ended questions.

However, findings also showed lower internal consistency of the Curriculum Evaluation subscale. This could be due to the curriculum differences between dental schools in the U.S. and in Latin America. To improve the internal consistency for Curriculum Evaluation, analysis and comparison between American and Latin American curriculum should be conducted. This analysis would assist researchers in 
understanding which questions in Curriculum Evaluation must be revised and adapted to the dental schools where the survey will be administered.

Compared to the alpha coefficients of the English version, HPV-OPC-KPCP-SV had a higher internal consistency in the following subscales: HPV and HPV-OPC Knowledge, HPV Vaccine Knowledge, and Scope of Practice. The English version had Cronbach's alpha coefficient of 0.71 and 0.79 for HPV and HPV-OPC Knowledge, and HPV Vaccine Knowledge, respectively. These two categories in the English version had lower value of Cronbach's alpha coefficient, probably due to the lower number of items-the English version had fewer items compared to the Spanish version. The English version had two items for Scope of Practice and thus was analyzed using Spearman correlation, which resulted in an alpha coefficient of 0.71 . This value was slightly lower than the Cronbach's alpha coefficient of Spanish Scope of Practice (0.73).

Previous researches in Latin America have evaluated different aspects related to HPV-OPC in dental students [28]. Each research group developed a questionnaire regarding dental students' demographic, sexual habits, sexual-related pre-existing pathologies, and HPV-OPC knowledge. Two studies claimed that their questionnaires were validated $[28,29]$. Although, there are no statistical reports and references in these studies that allows us to evaluate and compare the validation process of their questionnaires with ours. The description provided by the researchers were as followed: Medina et al. reported that experts validated their questionnaire with high reliability; on the other hand, Lama-González's group simply reported the implementation of a pilot study with dental students of La Facultad de Odontología de la Universidad Autónoma de Yucatan. In both studies, no reports were found in the publications about Cronbach's alpha coefficient or any statistical analysis used to validate their questionnaires [28, 29].

Even though the previous studies listed above were valuable in assessing dental students' knowledge regarding HPV-OPC, they did not demonstrate any methodological steps needed to claim validity of their new scales. HPV-OPC-KPCP-SV is the first to describe their validation methodology. Besides assessing dental students' knowledge, perception, and clinical practice, the current survey also assessed the HPVOPC curriculum in Latin American dental schools. The study results reveal a great opportunity for curriculum evaluation and development among Latin American dental schools and can be used to further implement research in Latin American countries regarding HPV-OPC. By comprehensively evaluating dental students' knowledge, perception, curriculum, and clinical practice, the barriers that prevent or limit the discussion of HPV-OPC and HPV vaccination with patients can be identified and mitigated. Knowing these barriers provides the foundation to propose a guide and/or intervention that would aim to increase HPV-OPC education among patients and increase HPV vaccination rates in Latin America.

\section{Limitations}

The HPV-OPC-KPCP-SV survey appears to have been successfully translated from English to Spanish. Moreover, the reliability and cross-cultural applicability is appropriate to be implemented in dental students from Latin America countries. However, in interpreting the results, it is important to take the 
study's limitations into account. Despite the success of the pilot testing of the HPV-OPC-KPCP-SV, the results could not be generalizable, as the study was not randomized. The study was conducted in only two countries: Mexico and Colombia, thus findings may not generalize to other Latin American countries. Nevertheless, people from different cultural and demographic background were included in this study and reliability was high suggesting that generalizability may be appropriate yet additional research is needed to support this claim.

This study administered one survey in a cross-sectional design meaning Cronbach's alpha was the only feasible reliability measure that could be assessed. The study could not measure test-retest reliability because the students were only asked to complete the survey once. Concurrent validity or discriminant reliability measures were not possible as the students were only asked to complete one survey. Floor and ceiling effects are also possible limitations in surveys of this type. Administering this survey to a wider range of other dental students and professionals, both in experience and knowledge, and at multiple time points would reduce these limitations.

After the survey was administered, there was an in-person group discussion. This may have limited the ability of participants to confidently express and share their feedback. Also, it is possible that the participants' responses could have been influenced by social desirability and conformity bias. Since participatns were relatively new to the dental school academic environment, they may have been knowingly or unknowingly responding to items while taking into consideration their peers or the researchers' perceptions of their responses. This was mitigated by an anonymous comment field that allowed the participants, who may feel uncomfortable to discus in the in-person group discussion, opportunities to provide their feedback. However, these biases could still exist.

Since the participants were first-year students, they might feel uncomfortable answering some questions in this pilot due to the limited patient hours and the knowledge regarding cancer-related topics. This limitation of knowledge may be the reason why the Curriculum Evaluation had a low alpha coefficient.

Future research should focus on the evaluation of knowledge that senior dental students (D4 and D5) as well as dentists and dental hygienists have about HPV Knowledge, HPV-OPC Knowledge, HPV Vaccine Knowledge, Barriers, Clinical Procedures, Scope of Practice, and Curriculum Evaluation in order to identify and overcome real or perceived barriers. This could take the form of offering continuing education courses, workshops, or changes in dental school curriculums. Subsequent studies should focus on further validation of the HPV-OPC-KPCP-SV and include assessment of additional reliably measures.

\section{Conclusions}

This study aimed to evaluate the applicability of a Spanish translation of an English survey developed for the US dental and dental hygiene student population in dental students from Latin America. Aside from assessing the linguistic and cultural equivalency of the Spanish version of the survey, this study found high internal consistencies for the majority of subscales examining HPV Knowledge, HPV-OPC Knowledge, HPV Vaccine Knowledge, Barriers, Clinical Procedures, and Scope of Practice. 
The process of a Spanish translation of the HPV-OPC-KPCP-SV survey demonstrated initial reliability and applicability for the assessment of the knowledge, perceptions, and clinical practices regarding HPV-OPC for dental students in Latin America. However, this is only a first step, the next step would be to do further reliability and validity assessments using a larger sample. This study has implications for dental HPV curriculum development and may be used to assess needs for improving the quality of dental practice among our future dental health professionals in the area of HPV education, HPV vaccination, and detection of HPV-OPC cancers at early stages.

\section{Declarations}

\section{Ethical Approval and consent to participate}

This study was approved by the University of Utah's and Institutional Review Board (IRB), also known as the university's ethics committee (IRB_00087209). All methods were performed in accordance with the relevant guidelines and regulations approved by University of Utah's IRB and ethics committee for this study (IRB_00087209). Participation was voluntary and completion of the questionnaire included a cover letter that served as informed consent as approved by the University of Utah's IRB or ethics committee. Informed consent was obtained from all participants.

\section{Consent for publication}

Not applicable

\section{Availability of data and materials}

The datasets have been attached as supplementary tables. The datasets used and/or analyzed during the current study will be made publicly available by May 2021. Please contact the corresponding author at deanna.kepka@hci.utah.edu to locate the publicly available data for this study.

\section{Competing interests}

None of the authors have a conflict of interest.

\section{Funding}

This study was funded by the Huntsman Cancer Foundation (PI: Kepka), the Dick and Tammy Burton Foundation (PI: Kepka), the University of Utah College of Nursing (PI: Kepka), and the University of Utah's Vice President for Research Faculty Research and Creative Grant Program (PI: Kepka). The REDCap application was funded by grant number 8UL1TR000105 (formerly UL1RR025764) NCATS/NIH) from the National Center for Advancing Translational Sciences of the National Institutes of Health. The findings and conclusions in this report are those of the authors and do not necessarily represent the official position of the National Institutes of Health 
L.P, D.K., S.A. and A.V. wrote and edited the manuscript. L.P, A.V., H.R, D.T., L.M., C.D., S.A., B.D., J.W., and D.K. contributed to the study design, survey development, survey administration, data analyses activities, and interpretation of results. L.P, A.V., H.R, D.T., L.M., C.D., S.A., B.D., J.W., and D.K. read and approved the final manuscript.

\section{Acknowledgements}

Our team would like to express our appreciation for the support Ms. Lisa Pappas, MS at Huntsman Cancer Institute for her statistical guidance and support. We would also like to express our appreciation for the dental student participants and dental faculty and staff at Universidad Autonoma de Baja California, Tijuana, Mexico and at Universidad de Antioquia, Medellín, Antioquia, Colombia.

\section{References}

1. Hussein AA, Helder MN, de Visscher JG, Leemans CR, Braakhuis BJ, de Vet HC, Forouzanfar T. Global incidence of oral and oropharynx cancer in patients younger than 45 years versus older patients: a systematic review. European Journal of Cancer. 2017 Sep 1;82:115-27.

2. Bray F, Ferlay J, Soerjomataram I, Siegel RL, Torre LA, Jemal A. Global cancer statistics 2018: GLOBOCAN estimates of incidence and mortality worldwide for 36 cancers in 185 countries. CA: a cancer journal for clinicians. 2018 Nov;68(6):394-424.

3. Ferlay J, Ervik M, Lam F, Colombet M, Mery L, Piñeros M, Znaor A, Soerjomataram I, Bray F. Global cancer observatory: cancer today. Lyon, France: International Agency for Research on Cancer. 2018 Dec 14.

4. IARC Working Group on the Evaluation of Carcinogenic Risks to Humans. IARC Monographs on the Evaluation of Carcinogenic Risks to Humans. A Review of Human Carcinogens. Vol 100. Part B: Biological Agents.

5. Serena-Gómez E, Bologna-Molina RE, Nevarez-Rascon A, Rocha Buelvas A. Prevalencia del VPH en el proceso de malignización de lesiones de vías aerodigestivas superiores. International journal of odontostomatology. 2011 Apr;5(1):5-12.

6. Chi AC, Day TA, Neville BW. Squamous cell carcinoma and precursor lesions of the oral cavity: epidemiology and aetiology. CA Cancer J Clin. 2015;65:401-21.

7. Dang J, Feng Q, Eaton KD, Jang H, Kiviat NB. Detection of HPV in oral rinse samples from OPSCC and non-OPSCC patients. BMC oral health. 2015 Dec 1;15(1):126.

8. Gipson BJ, Robbins HA, Fakhry C, D'Souza G. Sensitivity and specificity of oral HPV detection for HPV-positive head and neck cancer. Oral oncology. 2018 Feb 1;77:52-6.

9. Sullivan-Chang L, Saraiya M, Dunne EF, Brooks JT. More testing, more questions: screening tests for oral human papillomavirus infection. The Journal of the American Dental Association. 2017 Nov $1 ; 148(11): 781-3$. 
10. Food and Drug Administration (FDA). FDA approves expanded use of Gardasil 9 to include individuals 27 through 45 years old. Food and Drug Adminstration. 2018 Oct 5; https://www.fda.gov/news-events/press-announcements/fda-approves-expanded-use-gardasil-9include-individuals-27-through-45-years-old. Accessed 23 October 2020.

11. American Dental Association (ADA). Oral Health Topics: Cancer (Head and Neck). American Dental Association. https://www.ada.org/en/member-center/oral-health-topics/cancer-head-and-neck. Accessed 23 October 2020.

12. Kline N, Vamos C, Thompson E, Catalanotto F, Petrila J, DeBate R, Griner S, Vázquez-Otero C, Merrell L, Daley E. Are dental providers the next line of HPV-related prevention? Providers' perceived role and needs. Papillomavirus Research. 2018 Jun 1;5:104-8.

13. Kepka D, Rutkoski H, Pappas L, Tay DL, Winkler JR, Dixon B, Velazquez A, Pinzon LM. US oral health students' willingness to train and administer the HPV vaccine in dental practices. Preventive medicine reports. 2019 Sep 1;15:100957.

14. Sallam M, Al-Fraihat E, Dababseh D, Taim D, Zabadi S, Hamdan AA, Hassona Y, Mahafzah A, Şahin GÖ. Dental students' awareness and attitudes toward HPV-related oral cancer: a cross sectional study at the University of Jordan. BMC oral health. 2019 Dec 1;19(1):171.

15. Arora S, Ramachandra SS, Squier C. Knowledge about human papillomavirus (HPV) related oral cancers among oral health professionals in university setting-A cross sectional study. Journal of oral biology and craniofacial research. 2018 Jan 1;8(1):35-9.

16. Rajiah K, Maharajan MK, Num KS, Koh RC. Knowledge about human papillomavirus and cervical cancer: predictors of hpv vaccination among dental students. Asian Pacific Journal of Cancer Prevention: Apjcp. 2017;18(6):1573.

17. Lorenzo-Pouso Al, Gándara-Vila P, Banga C, Gallas M, Pérez-Sayáns M, García A, Daley EM, Gasamáns I. Human papillomavirus-related oral cancer: knowledge and awareness among Spanish dental students. Journal of Cancer Education. 2019 Aug 15;34(4):782-8.

18. Stull CL, Lunos S. Knowledge, Attitudes and Practices Regarding Human Papilloma Virus Communication and Vaccine Advocacy Among Minnesota Dentists and Dental Hygienists. American Dental Hygienists' Association. 2019 Feb 1;93(1):33-42.

19. Hashemipour MA, Parizi MT, Modares Y, Zadeh SP. Knowledge of Medical and Dental Iranian Students about the Infection and Vaccination of Human Papilloma Virus. Pesquisa Brasileira em Odontopediatria e Clínica Integrada. 2019;19.

20. Sezgin G, Pekiner, F. Assessing Oral Cancer Awareness Among Dental Students. J Canc Educ. 2019;34 (3):512-518.

21. Saranya M. Knowledge and Awareness on Oral Manifestation of Human Papilloma Virus (HPV) among Dental Students. Journal of Pharmaceutical Sciences and Research. 2017 Apr 1;9(4):486.

22. Pavão Spaulonci G, Salgado de Souza R, Gallego Arias Pecorari V, Lauria Dib L. Oral cancer knowledge assessment: Newly graduated versus senior dental clinicians. International journal of dentistry. 2018 Feb 13;2018. 
23. Amores Andrade MP. Nivel de conocimiento sobre el virus del papiloma humano (hpv) y su asociacion en cavidad oral: diagnostico, manifestaciones clínicas y tratamiento, en los estudiantes de 8vos, 9nos semestres en la Facultad de Odontologia de la Universidad Central del Ecuador periodo lectivo 2015-2016 (Bachelor's thesis, Quito: UCE).

24. Daley EM, Thompson EL, Vamos CA, Griner SB, Vazquez-Otero C, Best AL, Kline NS, Merrell LK. HPVrelated knowledge among dentists and dental hygienists. Journal of Cancer Education. 2018 Aug 1;33(4):901-6.

25. Rutkoski H, Fowler B, Mooney R, Pappas L, Dixon BL, Pinzon LM, Winkler J, Kepka D. Pilot test of survey to assess dental and dental hygiene student human papillomavirus-related oropharyngeal cancer knowledge, perceptions, and clinical practices. Journal of Cancer Education. 2018 Aug 1;33(4):907-14.

26. Northridge ME, Manji N, Piamonte RT, More FG, Katz RV. HPV, oropharyngeal cancer, and the role of the dentist: a professional ethical approach. Journal of Health Care for the Poor and Underserved. 2012;23(4):47-57.

27. Poelman MR, Brand HS, Forouzanfar T, Daley EM, Jager DH. Prevention of HPV-related oral cancer by dentists: assessing the opinion of Dutch dental students. Journal of cancer education. 2018 Dec 1;33(6):1347-54.

28. Lucrecia MM, Gabriel MM, Antonio ML. Risk behaviors and level of knowledge about human papillomavirus in Northeastern University, Argentina. Enfermedades Infecciosas y Microbiología. 2014;34(4):140-4.

29. Lama-González E, Godoy-Montañez C, Aguilar-Ayala FJ, Rejón-Peraza M, Gutiérrez-Solís A. Nivel de conocimientos de los estudiantes con respecto a la transmisión del VPH. Revista Odontológica Latinoamericana. 2008(1):61-4.

\section{Supplementary Files}

This is a list of supplementary files associated with this preprint. Click to download.

- RawDataColombia.xlsx

- RawDataMexico.xlsx 